\title{
PENINGKATAN AKSES REMAJA PADA LAYANAN PROGRAM KESEHATAN REPRODUKSI DENGAN PENERAPAN APLIKASI LAYANAN KEPERAWATAN KESEHATAN REPRODUKSI REMAJA (LAWAN ROMA) DI SMP N 2 BAWEN KABUPATEN SEMARANG
}

\author{
Dian Indriyani, Raharjo Apriyatmoko, Tina Mawardika \\ Program Studi S1 Keperawatan Universitas Ngudi Waluyo, Ungaran \\ Email :dindri897@gmail.com
}

\begin{abstract}
ABSTRAK
Akses remaja pada layanan kesehatan reproduksi belum optimal. Salah satu inovasi untuk meningkatkan akses remaja pada layanan kesehatan reproduksi adalah dengan penerapan aplikasi Lawan Roma. aplikasi ini berbasis Android/ IOS yang digunakan untuk memberikan pelayanan kesehatan reproduksi remaja berupa e-conseling, pendidikan kesehatan reproduksi, dan media pemberi informasi dari pelayanan kesehatan reproduksi dengan konsep KIE (Komunikasi, Informasi, dan Edukasi). Untuk mengetahui adanya peningkatan akses remaja pada layanan program kesehatan reproduksi dengan penerapan aplikasi Lawan Roma. Jenis desain dalam penelitian ini adalah pre-eksperimen dengan pendekatan one group pretest-posttest without control group design. Populasi penelitian ini adalah siswa-siswi SMP N 2 Bawen, Kabupaten Semarang. Pengambilan sampel menggunakan purposive sampling dengan jumlah sampel 19 responden. Instrument penelitian yang digunakan yaitu lembar self report dan database di aplikasi Lawan Roma. Analisa data menggunakan Uji Wilcoxon. Hasil penelitian menunjukkan bahwa sebelum penerapan aplikasi Lawan Roma nilai median 0 , standar deviasi 0,375 , dan nilai max sebesar 1 , sedangkan setelah penerapan aplikasi Lawan Roma nilai median 7, standar deviasi 2,65, dan nilai max 14. Sehingga adanya peningkatan akses remaja pada layanan program kesehatan reproduksi dengan penerapan aplikasi Lawan Roma. Hendaknya remaja dapat memanfaatkan aplikasi Lawan Roma untuk mengakses informasi dan layanan program kesehatan reproduksi.
\end{abstract}

\section{Kata Kunci : Akses Remaja, Aplikasi Lawan Roma, Kesehatan Reproduksi Remaja}

\section{ABSTRACT}

The Increase Of Adolescents Acces On Adolescents Reproduction Health Service Program By Applying Adolescents Reproduction Health Nursing Application Service (Lawan Roma) In SMP N 2 Bawen, Semarang Regency

Adolescents acces on reproduction health service is not optimal yet. One of innovations to increase adolescents acces on reproduction health service are applying Lawan Roma application. This application is Android/ IOS based application to give adolescents reproduction health service by e-conseling, reproduction health education, and reproduction health information giver using CIE (communication, information, and education). To know the increase of adolescents acces on adolescents reproduction health service program by applying adolescents reproduction health nursing application service (Lawan Roma). The research design used pre-experiment with one

Peningkatan Akses Remaja... (Dian Indriyani, Raharjo Apriyatmoko) 
group pretest-posttest without control group design. The research population were SMP N 2 Bawen students, Semarang Regency. Samples were 19 respondents by using purposive sampling. Instrument research used self report and Lawan Roma application database. Data analyze used Wilcoxon test. This research shows that before Lawan Roma application applied median value is 0 , deviation standard is 0.375 , and maximum value is 1, meanwhile after Lawan Roma application applied median value is 7, deviation standard are 2.65, and maximum value are 14. So, there is increase of adolescents acces on reproduction health service program by applying Lawan Roma application. It is expected that adolescents can use Lawan Roma application for information acces and reproduction health services program.

\section{Keywords : Adolescent acces, Lawan Roma application, Reproductive health of adolescent.}

\section{PENDAHULUAN}

Remaja adalah penduduk dalam rentang usia 10-19 tahun (WHO, 2015). Perubahan yang terjadi pada masa remaja dapat dilihat dari 3 dimensi, yaitu dimensi biologis, dimensi kognitif, dan dimensi moral (Marmi, 2015).

Pada usia remaja ingin mengetahui hal-hal baru, sehingga muncul perilaku ingin mencoba-coba dan terkadang menimbulkan masalah baru (Marmi, 2015). Salah satu masalah yang sering timbul pada remaja terkait dengan masa awal kematangan organ reproduksi pada remaja adalah perilaku seks bebas (free sex) masalah kehamilan yang terjadi pada remaja usia sekolah diluar pernikahan, dan terjangkitnya penyakit menular seksual termasuk HIV/AIDS (Kartika, 2010).

Indonesia merupakan Negara dengan pernikahan usia muda peringkat ke-37 di dunia dan urutan ke-2 di ASEAN (CSA and ICF Internasional, 2011). Badan Keluarga Berencana dan Pemberdayaan Perempuan (BKBPP) Kabupaten Semarang, melalui Tribun Jateng, menyatakan bahwa bahwa ada sekitar 8.000 pernikahan sepanjang 2015 dan tercatat sudah ada sekitar 2.214 perkara perceraian. Ada sekitar 216 pasangan melakukan pernikahan di bawah umur, angka tertinggi di Kecamatan Bandungan, Pringapus, Bergas, dan Bawen. Dilihat dari geografisnya, wilayah tersebut adalah wilayah industri dan hiburan malam sehingga dipetakan menjadi titik rawan untuk pernikahan dini (Setiawan, 2016).

Total kejadian persalian usia muda tahun 2016-September 2018 yaitu 59 kejadian dan jumlah kejadian terbanyak ada di desa Kandangan dan Lemah Ireng yaitu 17 kejadian. Di wilayah ini banyak terdapat remaja dikarenakan di wilayah tersebut terdapat SMP yang cukup besar yaitu SMP N 2 Bawen. Pada tahun 2016-September 2018 terlihat terjadi penurunan angka kejadian persalinan usia muda. Namun pada bulan Oktober (saat studi pendahuluan) terdapat 3 kasus baru kehamilan tidak diharapkan pada remaja dan masih dilakukan pendataan oleh Tim Puskesmas Bawen.

Pada tahun 2002, pengembangan program kesehatan remaja lebih diperluas dan dimantapkan dengan memperkenalkan Pelayanan Kesehatan Peduli Remaja (PKPR). Program ini menggunakan pendekatan yang berbeda, yaitu puskesmas diberikan keleluasan untuk berinovasi dan berkreativitas untuk meningkatkan akses remaja melalui pendekatan UKS, kegiatan karang taruna, dan anak jalanan serta kegiatan-kegiatan remaja lainnya yang dianggap potensial. (Rodrick, 2014). 
Secara umum kebutuhan riil menyangkut hak dasar remaja akan informasi terkait seksualitas dan kesehatan reproduksi antara lain penyediaan layanan ramah dan mudah diakses remaja, adanya jaminan kerahasiaan, penyediaan informasi yang bisa diakses sesuai dengan perkembangan remaja (Marmi, 2015).

Eratnya gadget dengan remaja menjadikan inovasi untuk dikembangkan aplikasi Layanan Keperawatan Kesehatan Reproduksi Remaja (Lawan Roma) berbasis android/ IOS. Aplikasi berbasis android/ IOS memungkinkan untuk dapat digunakan dalam memberikan pelayanan kesehatan reproduksi kepada remaja sehingga menjadi layanan ramah dan mudah diakses remaja, serta adanya jaminan kerahasiaan. Petugas kesehatan ataupun perawat dapat memberikan layanan kesehatan reproduksi remaja dengan mudah, jangkauan luas, praktis, hemat, dan efisien, sehingga remaja dapat berperan aktif dalam mengakses layanan kesehatan reproduksi.

Berdasarkan studi pendahuluan yang dilakukan peneliti kepada petugas kesehatan di Puskesmas Bawen pada 9 Oktober 2018, didapatkan data bahwa program kesehatan kepada remaja di Puskesmas Bawen kurang optimal. Pelayanan kesehatan kepada remaja kurang merata, termasuk dalam kesehatan reproduksi remaja. Hal ini dikarenakan puskesmas hanya bisa melakukan kunjungan 1 tahun sekali ke sekolah-sekolah untuk memantau kondisi remaja melalui petugas di UKS. Penyuluhan kesehatan kepada remaja hanya dilakukan dengan mengumpulkan perwakilan siswa untuk diberikan penyuluhan kesehatan di Puskesmas. Setiap sekolah mengirimkan 5 siswa yang kurang bisa mencakup keseluruhan sasaran yang banyak dan luas.

\section{METODE PENELITIAN}

Penelitian ini dilakukan pada tanggal 28 Februari 2019 - 8 Maret 2019 di SMP N 2 Bawen. Penelitian ini menggunakan rancangan preeksperimen, dengan desain one group pretest-posttest without control group design.

Populasi dalam penelitian ini adalah siswa-siswi di Sekolah Menengah Pertama (SMP) N 2 Bawen, Kabupaten Semarang yang berjumlah 167 orang.. Sampel dalam penelitian berjumlah 19 responden. Teknik pengampilan sampel menggunakan Purposive Sampling.

Dalam penelitian ini ada 2 varibael yaitu penerapan aplikasi Lawan Roma (Independen) dan peningkatan akses remaja pada layanan program kesehatan reproduksi (dependen). Instrumen pengumpulan data yang digunakan dalam penelitian ini adalah lembar self report dan database aplikasi Lawan Roma. Uji yang digunakan dalam penelitian ini adalah uji wilcoxon.

\section{HASIL DAN PEMBAHASAN}

Tabel 1. Distribusi Frekuensi Karakteristik Responden ( Umur Responden)

\begin{tabular}{cccccc}
\hline Karakteristik Umur & N & Median & Sd & Min & Max \\
\hline Responden & 19 & 13 & $\mathbf{0 , 7 1 3}$ & 12 & 14 \\
\hline
\end{tabular}

Berdasarkan table 1 menunjukkan nilai tengah umur responden 13 tahun, dengan standar deviasi 0,713. Umur minimal yang dimiliki responden yaitu 12 tahun, sedangkan umur maksimal 14 tahun.

\section{Tabel 2. Distribusi Frekuensi Karakteristik Responden (Jenis Kelamin)}

Karakteristik f $\%$




\begin{tabular}{|c|c|}
\hline $\begin{array}{c}\text { Judul } \\
\text { Gambar }\end{array}$ & $\begin{array}{c}\text { Frekuensi (f) } \\
\text { H1 H2 H3 H4 H5 H6 H7 }\end{array}$ \\
\hline Hindari PMS & $\begin{array}{lllllll}3 & 3 & 6 & 3 & 2 & 4 & 1\end{array}$ \\
\hline $\begin{array}{c}\text { Berencana } \\
\text { nikah muda? }\end{array}$ & $\begin{array}{lllllll}4 & 8 & 3 & 2 & 4 & 2 & 2\end{array}$ \\
\hline $\begin{array}{l}\text { Menikahlah } \\
\text { di usia ideal }\end{array}$ & $\begin{array}{lllllll}5 & 8 & 2 & 1 & 2 & 3 & 1\end{array}$ \\
\hline $\begin{array}{l}\text { Sekolah yes, } \\
\text { nikah muda } \\
\text { no way }\end{array}$ & $\begin{array}{lllllll}3 & 4 & 1 & 3 & 6 & 2 & 5\end{array}$ \\
\hline $\begin{array}{l}\text { Anda remaja, } \\
\text { anda beresiko }\end{array}$ & $\begin{array}{lllllll}8 & 4 & 2 & 2 & 2 & 2 & 1\end{array}$ \\
\hline Jumlah & $\begin{array}{lllllll}23 & 27 & 14 & 11 & 16 & 13 & 10\end{array}$ \\
\hline $\begin{array}{c}\text { Jenis } \\
\text { Kelamin }\end{array}$ & 47,37 \\
\hline $\begin{array}{r}\text { Perempuan } \\
\text { Laki-laki } \\
\end{array}$ & 52,63 \\
\hline $\begin{array}{r}\text { Berdasarl } \\
\text { responden berj } \\
\text { yaitu sebanyak } \\
\text { sedangkan je } \\
\text { berjumlah sam. }\end{array}$ & $\begin{array}{l}\text { an table } 2 \text { menunjukkan } \\
\text { nis kelamin perempuan } \\
9 \text { responden }(47,37 \%) \text {, } \\
\text { is kelamin laki-laki } \\
10 \text { responden }(52,63 \%) \text {. }\end{array}$ \\
\hline \multicolumn{2}{|c|}{$\begin{array}{l}\text { Tabel 3. Distribusi Frekuensi } \\
\text { Karakteristik Responden } \\
\text { (Penghasilan Orang Tua) }\end{array}$} \\
\hline Karakteristik & $\%$ \\
\hline $\begin{array}{c}\text { Penghasilan } \\
\text { Orang Tua } \\
\quad<\text { UMR } \\
\geq \text { UMR } \\
\end{array}$ & $\begin{array}{l}10,5 \\
89,5\end{array}$ \\
\hline
\end{tabular}

Berdasarkan table 3 menunjukkan penghasilan orang tua $<$ UMR yaitu sebanyak 2 orang tua responden (10,5\%), sedangkan penghasilan orang tua $\geq$ UMR berjumlah 17 orang tua responden $(89,5)$.

Tabel 4. Akses Remaja pada Layanan Program Kesehatan Reproduksi Sebelum Diterapkan Aplikasi Layanan Keperawatan Kesehatan Reproduksi Remaja (Lawan Roma). Berdasarkan tabel 4 dapat diketahui bahwa sebelum dilakukan penerapan aplikasi Lawan Roma nilai
Presentase (\%) $\begin{array}{llllllll}\text { H1 } & \text { H2 } & \text { H3 } & \text { H4 } & \text { H5 } & \text { H6 } & \text { H7 } & \sum \%\end{array}$

$\begin{array}{llllllllll}22 & 2,6 & 2,6 & 5,3 & 2,6 & 1,7 & 3,5 & 0,88 & 19,18\end{array}$

$\begin{array}{lllllllll}25 & 3,5 & 7,1 & 2,6 & 1,7 & 3,5 & 1,7 & 1,7 & 21,80\end{array}$

$\begin{array}{lllllllll}22 & 4,4 & 7,1 & 1,7 & 0,88 & 1,7 & 2,6 & 0,88 & 19,26\end{array}$

$\begin{array}{lllllllll}24 & 2,6 & 3,5 & 0,88 & 2,6 & 5,3 & 1,7 & 4,4 & 20,98\end{array}$

$\begin{array}{lllllllll}21 & 7,1 & 3,5 & 1,7 & 1,7 & 1,7 & 1,7 & 0,88 & 18,28\end{array}$

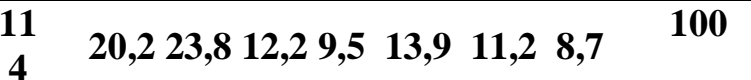

tengah dari akses remaja pada layanan program kesehatan reproduksi sebesar 0 akses, dengan standar deviasi 0.375 . Nilai minimal dari akses remaja pada layanan program kesehatan reproduksi adalah 0 akses dan nilai maksimal dari akses remaja pada layanan program kesehatan reproduksi adalah 1 akses.

Tabel 5. Distribusi Frekuensi Akses Media Gambar pada Aplikasi Layanan Keperawatan Kesehatan Reproduksi Remaja (Lawan Roma).

Berdasarkan tabel 5 menunjukkan bahwa selama 7 hari penerapan aplikasi Lawan Roma, remaja dalam mengakses gambar di aplikasi Lawan Roma paling banyak terjadi pada hari ke-2 yaitu sebesar 27 kali $(23,8 \%)$ akses gambar dan paling sedikit pada hari ke-7 yaitu

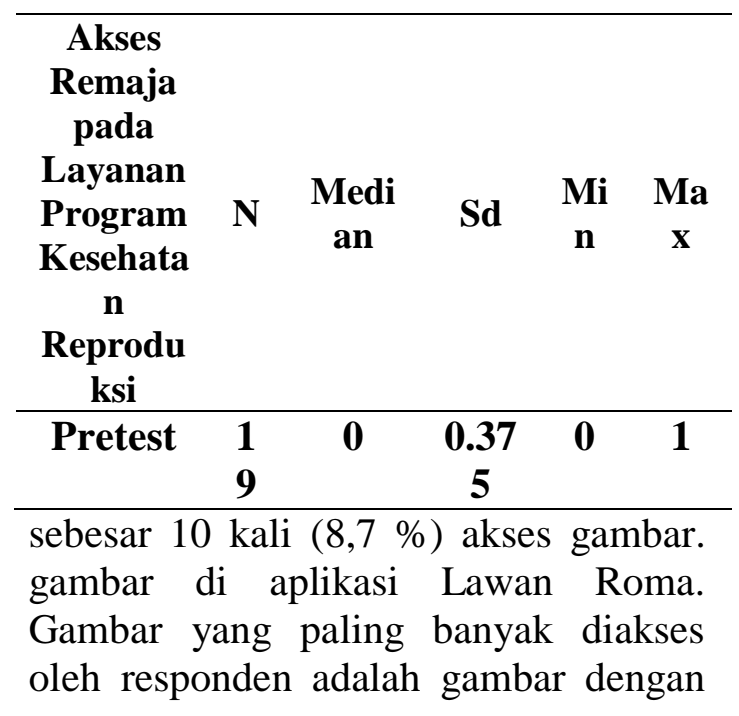


judul "Berencana nikah muda?" yaitu sebesar 25 kali akses.

Tabel 6. Distribusi Frekuensi Akses Media Video pada Aplikasi Layanan Keperawatan Kesehatan Reproduksi Remaja (Lawan Roma).

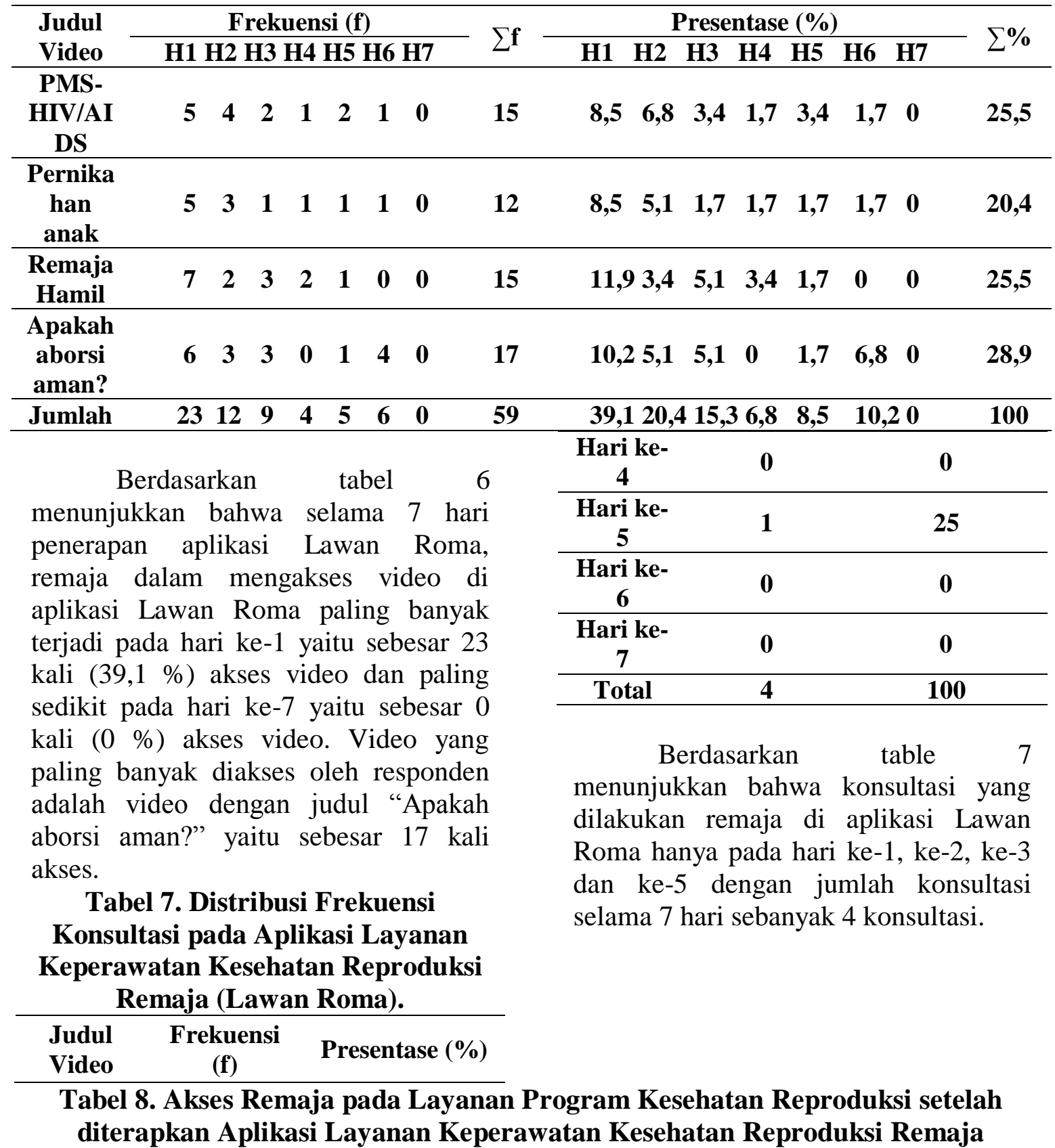

\begin{tabular}{ccc}
\hline $\begin{array}{c}\text { Hari ke- } \\
1\end{array}$ & 1 & 25 \\
\hline $\begin{array}{c}\text { Hari ke- } \\
2\end{array}$ & 1 & 25 \\
\hline $\begin{array}{c}\text { Hari ke- } \\
3\end{array}$ & 1 & 25 \\
\hline
\end{tabular}

Judul Frekuensi (f)

Video H1 H2 H3 H4 H5 H6 H7 Presentase (\%)

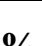
HIV/AI $\begin{array}{llllllll}5 & 4 & 2 & 1 & 2 & 1 & 0 & 15\end{array}$ (Lawan Roma).

\begin{tabular}{cccccc}
\hline $\begin{array}{c}\text { Akses Remaja pada } \\
\text { Layanan Program } \\
\text { Kesehatan } \\
\text { Reproduksi }\end{array}$ & N & Median & Sd & Min & Max \\
\hline Posttest & 19 & 7 & 2.65 & 4 & 14 \\
\hline
\end{tabular}


Berdasarkan tabel 8 dapat diketahui bahwa setelah dilakukan penerapan aplikasi Lawan Roma nilai tengah dari akses remaja pada layanan program kesehatan reproduksi sebesar 7 akses, dengan standar deviasi 2,65.

Tabel 9. Perbedaan Akses Remaja pada Media Gambar dan Media Video di Aplikasi Layanan Keperawatan Kesehatan Reproduksi Remaja (Lawan Roma)

\begin{tabular}{cccccccc}
\hline Variabel & Akses & N & Median & Sd & Min & Max & $\begin{array}{c}\text { P } \\
\text { value }\end{array}$ \\
\hline $\begin{array}{c}\text { Akses Remaja pada } \\
\text { Gambar dan Video di }\end{array}$ & Gambar & 19 & 3 & 1,99 & 1 & 8 & \\
Aplikasi Lawan Roma & & & & & & & 0,027
\end{tabular}

Video

19

$\begin{array}{lll}1,5 & 1,95 & 0\end{array}$

7

Roma sebesar 1,5 akses dengan standar

Berdasarkan tabel 9 dapat diketahui bahwa nilai tengah akses gambar di aplikasi Lawan Roma sebesar 3 akses dengan standar deviasi 1,99, nilai minimal 1 akses dan nilai maksimal 8 akses. Sedangkan nilai tengah akses video di aplikasi Lawan

Tabel 10. Perbedaan Akses Remaja pada Media Gambar dan Konsultasi di Aplikasi Layanan Keperawatan Kesehatan Reproduksi Remaja (Lawan Roma)

\begin{tabular}{cccccccc}
\hline Variabel & Akses & N & Median & Sd & Min & Max & P value \\
\hline $\begin{array}{c}\text { Akses Remaja } \\
\text { pada Gambar }\end{array}$ & Gambar & 19 & 3 & 1,99 & 1 & 8 & $\mathbf{0 , 0 0 1}$ \\
$\begin{array}{c}\text { dan Konsultasi } \\
\text { di Aplikasi }\end{array}$ & & & & & & \\
Lawan Roma & $\begin{array}{c}\text { Konsulta } \\
\text { si }\end{array}$ & 19 & 0 & 0,42 & 0 & & \\
\hline
\end{tabular}

Berdasarkan tabel 10 dapat diketahui bahwa nilai tengah akses gambar di aplikasi Lawan Roma sebesar 3 akses dengan standar deviasi 1,99, nilai minimal 1 akses dan nilai maksimal 8 akses. Sedangkan nilai tengah akses konsultasi di aplikasi

Lawan Roma sebesar 0 akses dengan standar deviasi 0,42 , nilai minimal 0 akses dan nilai maksimal 1 akses. Hasil $p$ value $(0,001)<\alpha(0,05)$ artinya adanya perbedaan yang signifikan antara akses remaja pada gambar dan konsultasi di aplikasi Lawan roma.

Tabel 11. Perbedaan Akses Remaja pada Media Video dan Konsultasi di Aplikasi Layanan Keperawatan Kesehatan Reproduksi Remaja (Lawan Roma)
Akses
P value 


\begin{tabular}{cccccccc}
\hline $\begin{array}{c}\text { Akses Remaja pada } \\
\text { Video dan Konsultasi di } \\
\text { Aplikasi Lawan Roma }\end{array}$ & Video & 19 & 1,5 & 1,95 & 0 & 7 & 0,001 \\
\end{tabular}

$\begin{array}{llllll}\text { Konsultasi } & 19 & 0 & 0,42 & 0 & 1\end{array}$

\begin{abstract}
Berdasarkan tabel 11 dapat diketahui bahwa nilai tengah akses video di aplikasi Lawan Roma sebesar 1,5 akses dengan standar deviasi 1,95, nilai minimal 0 akses dan nilai maksimal 7 akses. Sedangkan nilai tengah akses konsultasi di aplikasi Lawan Roma sebesar 0 akses dengan standar deviasi 0,42 , nilai minimal 0 akses dan nilai maksimal 1 akses. Hasil $p$ value $(0,001)<\alpha(0,05)$ artinya adanya perbedaan yang signifikan antara akses remaja pada video dan konsultasi di aplikasi Lawan roma.
\end{abstract}

\section{PEMBAHASAN}

Hasil penelitian ini menunjukkan akses remaja pada layanan program kesehatan reproduksi sebelum penerapan aplikasi Lawan Roma rendah. Informasi mengenai layanan program kesehatan reproduksi untuk remaja (siswa-siswi SMP N 2 Bawen) sangat minim, sehingga akses remaja ke layanan program kesehatan reproduksi sangat sedikit yaitu nilai maksimal akses 1 . Hal ini sesuai dengan hasil penelitian Ida, Zahroh, dan Antono (2011) menyebutkan bahwa pemanfaatan layanan kesehatan reproduksi remaja di Kabupaten Batang (PKPR dan PIK KRR) secara umum masih rendah, dikarenakan informasi yang didapatkan remaja tentang layanan kesehatan reproduksi remaja belum didapatkan secara detail dan kebutuhan layanan remaja belum terpenuhi sesuai harapan remaja.

Setelah dilakukan penerapan aplikasi Lawan Roma, terlihat terjadi peningkatan akses remaja ke layanan kesehatan reproduksi, dengan hasil akses media gambar di aplikasi Lawan Roma paling banyak. Hal ini dikarenakan informasi yang ada di dalam gambar tersampaikan secara sederhana karena terlihat dalam satu waktu yang memperlihatkan ilustrasi lebih jelas dan mudah dimengerti sehingga menimbulkan ketertarikan responden dalam mengakses gambar. Hal ini sejalan dengan hasil penelitian Zakiyatul, Asep, dan Fajar (2017) menyatakan bahwa poster bentuknya yang sederhana dan mudah ditempel dimana saja memudahkan pembaca untuk membaca poster tersebut tanpa harus mencarinya terlebih dahulu. Gambar yang paling banyak diakses remaja yaitu gambar dengan judul "Berencana nikah muda?". Gambar ini berisi tentang efek yang ditimbulkan jika melakukan nikah di usia muda. Nikah di usia muda bisa terjadi dikarenakan beberapa faktor, salah satunya adalah kehamilan tidak diinginkan. Berdasarkan keterangan responden kejadian kehamilan tidak diinginkan (KTD) banyak terjadi dilingkungan responden sehingga banyak kejadian nikah muda. Selain itu, beberapa responden mengungkapkan ketakutan akan kehilangan pasangan (pacar) sehingga responden ada rasa ketertarikan untuk nikah muda dan menjadikan responden tertarik untuk melihat informasi tentang nikah muda. Hasil penelitian ini didukung dengan penelitian Mubasyaroh (2016) yang membahas tentang faktor penyebab pernikahan dini menyatakan bahwa beberapa faktor terjadinya pernikahan dini sangat bervariasi diantaranya 
adalah karena faktor ekonomi, perjodohan, ingin melanggengkan hubungan, dan MBA (married by accident).

Pada akses video lebih sedikit dibandingkan dengan akses gambar. Hal ini dikarenakan informasi dalam video tidak langsung terpaparkan dalam satu waktu. Selain itu dalam mengakses video dibutuhkan durasi yang lebih banyak dibandingkan dengan mengakses gambar, sehingga membuat resposden merasa bosan dan lebih tertarik dengan gambar yang lebih praktis untuk melihat informasi tentang kesehatan reproduksi. Hal ini sejalan dengan penelitian Yulius (2016) tentang peranan desain komunikasi visual sebagai pendukung promosi kesehatan menyatakan sebagai pendukung komunikasi suatu media promosi kesehatan, ilustrasi dibutuhkan sebagai pendamping teks, karena pada umumnya masyarakat lebih berkesan melihat suatu teks informasi yang ditampilkan dengan foto atau gambar ilustrasi (infografik).

Video yang paling banyak diakses remaja yaitu video dengan judul "Apakah aborsi aman?". Video ini berisi tentang definisi aborsi, jenis aborsi dan efek dari aborsi. Hasil ini memberikan makna bahwa minat dan kebutuhan responden terhadap pengetahuan dan informasi tentang aborsi banyak dikarenakan rasa penasaran dan banyaknya pula kehamilan tidak diinginkan, sehingga akses video "Apakah aborsi aman" menjadi daya tarik tersendiri oleh responden.

Pada penelitian ini konsultasi yang dilakukan remaja masih sedikit. Hal ini dipengaruhi oleh tingkat pengetahuan yang dimiliki responden tentang konsultasi. Penelitian Wulandari (2015) tentang pemanfaatan PIK-R yang menyatakan bahwa pengetahuan tinggi berpeluang memanfaatkan PIK-R (Pusat
Informasi Konseling Remaja) sebanyak 2,95 kali dibandingkan pengetahuan rendah, begitu juga dengan sikap responden yang memiliki sikap positif berpeluang 2,25 kali untuk memanfaatkan PIK-R.

Akses remaja pada konten gambar berbeda dengan akses remaja ke konten video. Gambar dan video merupakan media yang sama-sama memperlihatkan visual. Namun video memiliki perbedaan dengan gambar yaitu video menghasilkan suara dan informasi yang tersampaikan berdasarkan durasi dalam video, sedangkan gambar informasi tersampaikan secara langsung dalam satu muka. Hal ini didukung dengan hasil penelitian Prita, Toto, dan Rendra (2016) tentang efektivitas penggunaan video dan buku bergambar dalam meningkatkan pengetahuan yang mengungkapkan bahwa terdapat perbedaan nilai pengetahuan yang signifikan antara kelompok buku bergambar dan video pada saat posttest, buku bergambar lebih efektif dibandingkan video. Pada penelitian tersebut, hal itu dapat terjadi karena pada saat media video diputar, gambar yang berisi pesan yang ingin disampaikan bergerak terus, sehingga tidak semua responden mampu menangkap informasi.

Pada penelitian ini remaja lebih memilih untuk melihat gambar dan video untuk membaca informasi yang ada di gambar dibandingkan untuk konsultasi. Konsultasi kurang diminati remaja karena takut membuka privasi remaja dan remaja berfikir bahwa itu merupakan konsumsi pribadi. Sebelum penelitian, peneliti telah melakukan inform consent dan menjelaskan tentang kerahasian data penelitian dan konsultasi, sehingga masih terdapat responden yang melakukan konsultasi, walaupun jumlahnya sedikit. Hal serupa juga diungkapkan pada penelitian Mirawati (2015) tentang media 
konsultasi online sebagai alternatif upaya penanganan masalah remaja. Pada penelitian tersebut diungkapkan bahwa Pada umumnya para remaja berharap, jika mereka mengkonsultasikan masalah mereka, maka permasalahan itu harus sangat dijaga kerahasiaannya.

Adanya peningkatan akses remaja pada layanan program kesehatan reproduksi dengan penerapan aplikasi Lawan Roma yang berkaitan dengan efek teknologi dan internet terhadap promosi dan prevensi kesehatan reproduksi. Pernyataan ini didukung dengan penelitian Ari, Herlina, dan Hendra (2015) tentang efek penerapan peer konselor berbasis KERIS-Net yang menyatakan bahwa pengintegrasian antara pemberdayaan peer konselor dengan pemanfaatan kemajuan teknologi dapat dilakukan melalui KERIS-Net (Kelompok Remaja Sehat Berbasis Internet). Keseluruhan proses promosi kesehatan dapat dioptimalkan dengan pemanfaatan teknologi internet melalui KERIS-Net.

\section{KESIMPULAN DAN SARAN}

Berdasarkan hasil dan pembahasan pada bab sebelumnya, maka dapat diperoleh kesimpulan dari penelitian ini, yaitu Karakteristik responden berjenis kelamin laki-laki berjumlah 10 responden $(52,63 \%)$. Umur mempengaruhi tingkat pengetahuan yang dimiliki responden. Akses remaja di layanan program kesehatan reproduksi sebelum dilakukan penerapan aplikasi Lawan Roma memiliki nilai tengah sebesar 0 akses, dengan standar deviasi 0.375. Akses remaja di layanan program kesehatan reproduksi setelah dilakukan penerapan aplikasi Lawan Roma memiliki akses gambar sejumlah 114 akses, akses video sejumlah 59 akses dan konsultasi sebanyak 4 akses. Hal ini menunjukkan terdapat peningkatan akses remaja di layanan program kesehatan reproduksi dengan penerapan aplikasi Lawan Roma Akses media gambar lebih banyak dibandingkan akses media video dan akses konsultasi di aplikasi Lawan Roma. Gambar yang paling banyak diakses oleh responden adalah gambar dengan judul "Berencana nikah muda?" yaitu sebesar 25 kali akses. Adanya perbedaan antara akses media gambar dan media video, akses media gambar dan konsultasi, akses media video dan konsultasi.

Berdasarkan kesimpulan dari penelitian yang ada, maka penulis memberikan beberapa saran-saran yaitu aplikasi Lawan Roma ini dapat digunakan oleh perawat dan tenaga kesehatan dalam memberikan tindakan promosi kesehatan terkait kesehatan reproduksi sebagai salah satu bentuk pemberian intervensi dengan pendekatan teknologi. Hasil penelitian ini diharapkan dapat menjadi evideneed based penelitian-penelitian selanjutnya terkait akses remaja pada layanan program kesehatan reproduksi dan penerapan aplikasi layanan keperawatan kesehatan reproduksi remaja (lawan roma).

\section{DAFTAR PUSTAKA}

Ari Pristiana Dewi, Herlina, dan Hendra Taufik. (2015). Efek Penerapan Peer Konselor Berbasis KERISNet terhadap Perubahan Perilaku Seksual. Jurnal Keperawatan Soedirman 10 (3).

Central Statistical Agency [Ethiopia] and ICF International. (2012). Ethiopia Demographic and Health Survey 2011. Addis Ababa, Ethiopia and Calverton, Maryland, USA: Central Statistical Agency and ICF International. 
Darmadi. (2018). Remaja dan Seks. Lampung: Guepedia.com.

Kementerian kesehatan RI. (2010). Riset Kesehatan Dasar (Riskesdas) 2010. Jakarta: Badan penelitian dan pengembangan kesehatan, Kemenkes RI.

Kartika, Ratna Pertiwi. (2010). Kesehatan Reproduksi Remaja dan Permasalahannya. Yogyakarta: FMIPA UNY.

Marmi. (2015). Kesehatan Reproduksi. Cetakan ketiga. Yogyakarta: Pustaka Pelajar.

Mirawati, Ira. (2015). Media Konsultasi Online Sebagai Alternatifupaya Penanganan Masalah Remaja. EduLib 5 (1).

Mubasyaroh. (2016). Analisis Faktor Penyeba Pernikahan Dini dan Dampaknya bagi Pelakunya. Jurnal Pemikiran dan Penelitian Sosial Keagamaan 7 (2).

Prita Devy Igiany, Toto Sudargo, dan Rendra Widyatama. (2016). Efektivitas penggunaan video dan buku bergambar dalam meningkatkan pengetahuan, sikap, dan keterampilan ibu mencuci tangan memakai sabun. BKM Journal of Community Medicine and Public Health 32 (3): 89-94.

Rodrick, Juraman Stefanus. (2014). Pemanfaatan Smartphone Android Oleh Mahasiswa Ilmu Komunikasi Dalam Mengakses Informasi Edukatif. Journal Fispol Unsrat 3 (1)

Setiawan, Deni. (2016). Romlah Prihatin Ada 216 Pernikahan
Dini di Kabupaten Semarang., http://jateng.tribunnews.com/2016 /01/08/romlah-prihatin-ada-216pernikahan-dini-di-kabupatensemarang. [17 Oktober 2018].

Yulius, Yogef. (2016). Peranan Desain Komunikasi Visual sebagai Pendukung Media Promosi Kesehatan. Jurnal Seni Desain dan Budaya 1 (2).

Zakiyatul Ulya, Asep Iskandar, Dan Fajar Tri Asih. (2017). Pengaruh Pendidikan Kesehatan Dengan Media Poster Terhadap Pengetahuan Manajemen Hipertensi Pada Penderita Hipertensi. Jurnal Keperawatan Soedirman 12 (1).

Ida Susilaksmi, Zahroh Shaluhiyah, dan Antono Suryoputro. (2011). Kebutuhan dan Pemanfaatan Layanan Kesehatan Reproduksi Remaja. Jurnal Promosi Kesehatan Indonesia 6 (1)

Wulandari, Sri. (2015). Hubungan Pengetahuan, Sikap Dan Perilaku Pencegahan Penyakit Menular Seksual (PMS) Dan HIV/AIDS Dengan Pemanfaatan Pusat Informasi Konseling Remaja (PIKR) Pada Remaja SMKN Tandun Kabupaten Rokan Hulu. Jurnal Maternity and Neonatal 2 (1). 